\title{
Efficacy and safety of prophylactic use of ketamine for prevention of postanesthetic shivering: a systematic review and meta analysis
}

\author{
Yang Zhou ${ }^{1+}$, Abdul Mannan ${ }^{1+}$, Yuan Han ${ }^{1}$, He Liu$^{1}$, Hui-Lian Guan ${ }^{1}$, Xing Gao ${ }^{1}$, Ming-Sheng Dai ${ }^{1}$
} and Jun-Li CaO ${ }^{1,2^{*}}$ (i)

\begin{abstract}
Background: Postanesthetic shivering is a common complication of anesthesia, which accounts for much discomfort in postoperative patients and may increase postoperative complications in high-risk patients. Due to the lack of high-quality evidence, it is difficult to draw a conclusion about optimal anti-shivering medication. The main purpose of this meta-analysis was to analyze and evaluate the efficacy and safety of prophylactic use of ketamine for preventing postanesthetic shivering.

Methods: We searched the following databases: Medline, Embase, and the Cochrane Central Register of Controlled Trails for randomized controlled trials. The primary outcome observed was the difference of the incidence rate of postanesthetic shivering between ketamine group and placebo group. The secondary outcomes were the sedation score and incidence of the side effects caused by ketamine and any other drugs utilized in the studies.

Results: In this meta-analysis, we analyzed a total of 16 trials including 1485 patients. Ketamine reduced the incidence rate of postanesthetic shivering compared to a placebo (odds ratio [OR]: 0.13, 95\% confidence interval [CI]: 0.06 to $0.26, P<0.01)$. Regarding side effects, there was no evident variability of the incidence of nausea and vomiting. Usage of ketamine was associated with a lower rate of hypotension and bradycardia when compared to a placebo. Hallucinations were more frequently observed in patients who received higher doses of ketamine. No significant difference was found in the incidence of postanesthetic shivering with ketamine versus other pharmacological interventions.
\end{abstract}

Conclusions: Ketamine can prevent postanesthetic shivering without severe side effects. However, ketamine shows no advantage over other anti-shivering drugs.

Keywords: Postanesthetic shivering, Anti-shivering, Ketamine

\section{Background}

Postanesthetic shivering is a frequent complication of anesthesia, perhaps even aggravating pain. It is characterized by involuntary movement that may affect one or more muscle groups and is a very unpleasant and physiologically stressful experience. Postanesthetic shivering can interfere

\footnotetext{
*Correspondence: junlicao0310@163.com

${ }^{\dagger}$ Yang Zhou and Abdul Mannan contributed equally to this work.

'Department of Anesthesiology, The Affiliated Hospital of Xuzhou Medical University, Xuzhou 2210002, Jiangsu, China

${ }_{2}^{2}$ Jiangsu Province Key Laboratory of Anesthesiology, Xuzhou Medical University, Xuzhou 221004, Jiangsu, China
}

with electrocardiography (ECG) and oxygen saturation (SpO2) monitoring [1]. More importantly, it can increase oxygen consumption combined with minute ventilation and carbon dioxide production. Moreover, it is believed that postanesthetic shivering can increase mortality in the elderly and patients with coronary artery disease [2].

The aetiology of shivering is not sufficiently understood. Thermoregulatory and non-thermoregulatory factors may contribute to postoperative shivering including exposure to cold weather, inadequate pain control, and opioid withdrawal $[3,4]$. The gold standard for treatment and

(c) The Author(s). 2019 Open Access This article is distributed under the terms of the Creative Commons Attribution 4.0 International License (http://creativecommons.org/licenses/by/4.0/), which permits unrestricted use, distribution, and 
prevention has not yet been defined. A variety of pharmacological treatments and methods to reduce postoperative shivering have been used including meperidine, alfentanil, tramadol, magnesium sulfate, ondansetron, dolasetron, and dexmedetomidine [5-9]. Ketamine has also been used as an anti-shivering drug. It is a non-competitive $\mathrm{N}$ methy-D-aspartate (NMDA) receptor antagonist; it may prevent postanesthetic shivering by decreasing core-toperipheral heat distribution. Although many published literatures have investigated the potential effects of ketamine for prevention of postanesthetic shivering, there is no consensus regarding the appropriateness of this drug. Thus, an evidence-based understanding of the benefits and risks of ketamine would identify its rational and optimal use. We conducted the meta-analysis to assess the efficacy and safety of ketamine for the prevention of shivering in patients undergoing various surgical procedures.

\section{Methods}

This meta-analysis was conducted and reported according to the Preferred Reporting Items for Systematic Reviews and Meta-Analysis (PRISMA) guidelines.

\section{Search strategy}

Two authors (Y.Z., A.M.) independently searched MEDLINE (2000 to March 2018), EMBASE (2000-2018), and the Cochrane Central Register of Controlled Trails (March 2018) with no language restrictions. By reviewing the references of the eligible articles, we identified additional studies relevant to our meta-analysis. The following search-term strategy was used:

1) shivering; 2) tremor; 3) shake; 4) hypothermia; 5) anesthesia; 6) postanesthetic; 7) postoperative; 8) surgery; 9) ketamine; 10) 1 or 2 or 3 or 4 ; 11) 5 or 6 or 7 or 8;12) 9 and 10 and 11.

\section{Criteria for considering studies for this review}

The selection criteria were pre-established. Inclusion criteria were: (1) controlled clinical trial; (2) prophylactic use of ketamine compared with a placebo or other pharmacological interventions; (3) reported the incidence of postoperative shivering. Trials were not considered for the following reasons: (1) other anti-shivering drugs were also administrated during the anesthetic induction or maintenance period besides ketamine; (2) data from abstracts, letters, or reviews. We included any participants undergoing operative procedures with general or spinal anesthesia. The following outcomes were measured: (1) incidence of postanesthetic shivering; (2) sedation score; (3) incidence of other side effects.

\section{Data collection and analysis}

Two review authors (Y.Z., A.M.) independently screened all the titles and abstracts of the studies during the initial search to identify the included studies. After removing the duplicates, potentially relevant studies were retrieved in full-text version for the further assessment. We resolved any disagreement by discussion with another author (G. H. L) of our group.

Data extraction was conducted by two authors (Y.Z., A.M.) independently using the data collection form established previously. The following data were collected from each study: primary author, publication year, anesthetic methods, demographic characteristics of participants, surgery types, comparisons, and other nonpharmacological warming methods. We recorded the number of patients experiencing shivering in each group for dichotomous data.

We used the Review Manager software of the Cochrane Collaboration (RevMan 5.2) to perform the quantitative analysis. The results of dichotomous data are expressed as odds ratio (OR) and 95\% confidence intervals (CIs). Heterogeneity testing was performed with $\mathrm{Z}$ score and $\mathrm{X}^{2}$ statistical analysis; $P<0.1$ was considered to indicate heterogeneity. The fixed effect model or the random effect model were applied according to the heterogeneity of the study. A fixed effect model was used when $\mathrm{I}^{2}<50 \%$. We reported the results of included studies when the pooled analysis was not appropriate. Sensitivity and subgroup analysis were performed to explore the reason for the heterogeneity. Subgroup analysis was conducted based on the anesthetic methods, various doses of ketamine used, and the types of surgery. Publication bias was evaluated by Begg's test using Stata 13.1 software (Stata, College Station, TX, USA).

\section{Results}

Search results and characteristics of the studies

The flow chart (Fig. 1) shows the process by which the selected studies were searched. A total of 361 potential articles were identified. We reviewed 30 full-text articles, after screening the titles and the abstracts. A total of 16 [10-25] studies including 1485 patients met our selection criteria and were included in the analysis (Table 1).

In 15 trials, participants were adults. One trial [23] included children aged 5-12 years. Participants in seven trials $[10,12,13,18,19,23,24]$ underwent operations under general anesthesia; participants in nine trials $[11,14-17,20$ $22,25]$ were under spinal anesthesia. In 13 trials [10, 12, 14-23] ketamine was compared to placebo; in 4 trials [12, $13,23,24]$ ketamine was compared to pethidine; in the other 4 trials $[11,15,16,22]$ ketamine was compared to tramadol. Ketamine was also compared to ondansetron in 4 trials $[10,15,17,21]$.

The administration time and routes were different among included trials. In 10 trials [11, 14-17, 20-23, 25] the intervention drugs were given immediately after induction of anesthesia or intrathecal injection; in five 


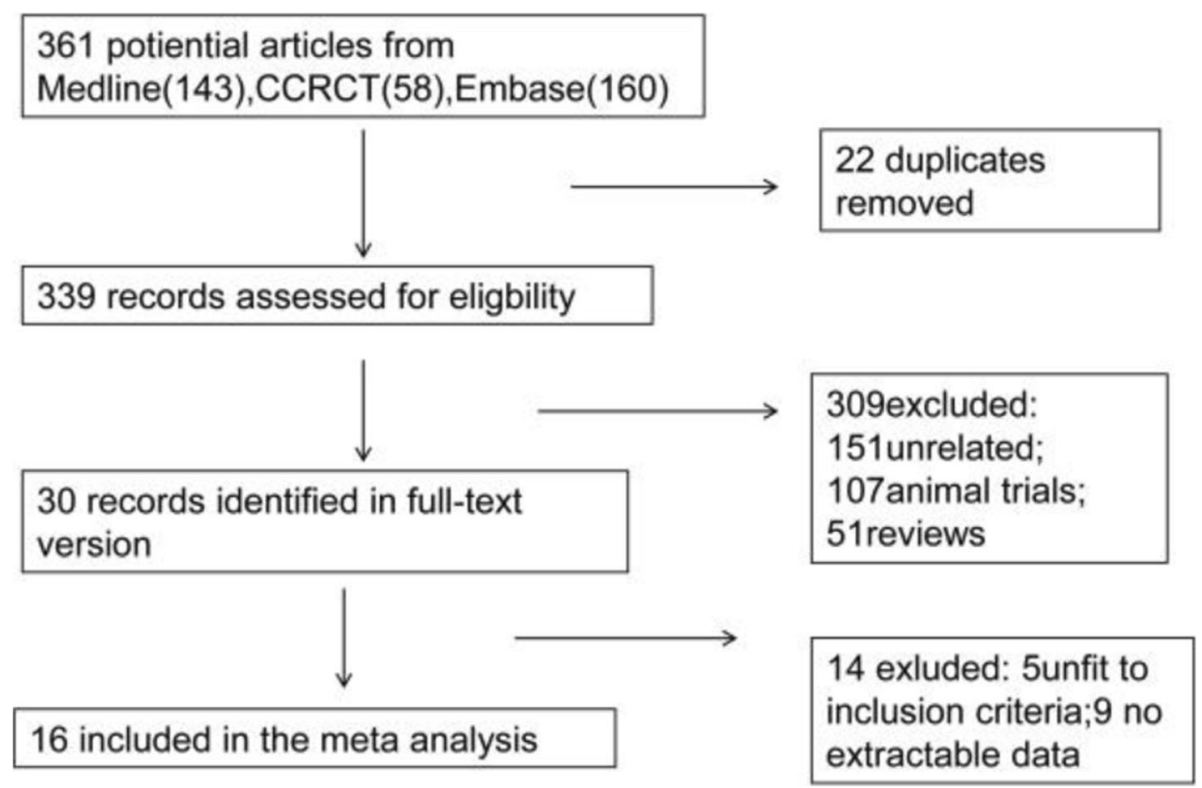

Fig. 1 Flow diagram showing the process of studies selection

trials $[10,12,18,19,24]$ drugs were administrated before completion of the surgical procedure; in one trial [13] patients received study drugs before wound closure. Study drugs were given as an IV bolus in 14 trials [10-22, 24]; in two trials, patients received the study drugs epidurally [25] or intramuscularly [24]. In four trials $[14,15,18,19]$, patients underwent orthopedic surgery; patients in two studies [21, 22] underwent abdominal surgery; patients in two studies $[16,17]$ underwent cesarean section; patients in two studies $[20,25]$ underwent urological surgery; in three trials, participants received ENT surgery [10], endoscopic sinus surgery [12], or tonsillectomy surgery [23].

Regarding measurement of intensity of shivering in a patient, 13 trials [10,13-17, 19-25] utilized a scale with variation points ranging from 0 to $4: 0=$ no shivering; $1=$ piloerection or peripheral vasoconstriction, but no visible shivering; 2 =muscular activity in only one muscle group; $3=$ muscular activity in more than one muscle group, but not generalized; $4=$ shivering involving the whole body. One trial [12] applied a 0-3 scale for evaluating the intensity: $0=$ no shivering; $1=$ mild fasciculation of face or neck muscles; $2=$ visible tremor involving more than one muscle; $3=$ gross muscular activity involving the entire body. Two studies $[11,18]$ did not assess the intensity of postanesthetic shivering.

\section{Assessment of the risk of bias in the included studies}

Two authors (Y.Z., A.M.) independently assessed the following domains using the Cochrane 'Risk of bias' tool:

- Sequence generation
- Allocation concealment

- Blinding of participants, personnel

- Blinding of outcome assessment

- Incomplete outcome data

- Selective outcome reporting

- Other bias

We completed 'Risk of bias' figures for each included study (Fig. 2). See more details in Appendix.

\section{Publication bias}

Begg's test showed that there was no publication bias for the primary outcome $(p=0.055)$.

\section{Effects of interventions \\ Primary outcome Ketamine vs placebo}

The incidence of postanesthetic shivering was compared between ketamine and a placebo in 13 trials including 1166 patients (Fig. 3). Ketamine has been shown to significantly decrease the incidence of shivering (pooled $\mathrm{OR}=0.13 ; 95 \% \mathrm{CI}: 0.06$ to $0.26, P<0.00001$ ). There was significant and prominent heterogeneity for this outcome $\left(\mathrm{I}^{2}=74 \%\right)$. Begg's test showed that there was no risk of publication bias $(P=0.06)$. A subgroup analysis was performed to explore the evidence-based reason. In subgroup analysis of anesthetic methods, the heterogeneity was $67 \%$ in the GA (general anesthesia) group (Fig. 4). Sensitivity analysis was performed; a trial [22] was removed which utilized an air forced warmer intraoperatively, which showed a similar result favoring ketamine (pooled OR $=0.18$; 95\% CI: 0.09 to 0.37 ) and decreased heterogeneity ( $\mathrm{I}^{2}$ from 67 to $21 \%$ ). Ketamine 
Table 1 Summary of Characteristics of Included Studies

\begin{tabular}{|c|c|c|c|c|c|c|}
\hline \multirow[t]{2}{*}{ Study ID } & \multirow[t]{2}{*}{ Participants } & \multirow[t]{2}{*}{ Surgery Types } & \multirow{2}{*}{$\begin{array}{l}\text { Anesthesia } \\
\text { Methods }\end{array}$} & \multicolumn{2}{|l|}{ Comparison } & \multirow{2}{*}{$\begin{array}{l}\text { Non-pharmacological } \\
\text { Warming Methods }\end{array}$} \\
\hline & & & & Control Group & Intervention Group & \\
\hline Sagir 2007 & $\begin{array}{l}160 \text { patients } \\
18-65 \mathrm{yr}\end{array}$ & $\begin{array}{l}\text { urological } \\
\text { surgery }\end{array}$ & SA & C(40): saline iv & $\begin{array}{l}\mathrm{K}(40): \mathrm{ketamine} 0.5 \mathrm{mg} / \mathrm{kg} \text { iv; } G(40) \text { : } \\
\text { granisetron } 3 \mathrm{mg}, \mathrm{iv} ; \mathrm{KG}(40) \text { ketamine } \\
0.25 / \mathrm{kg} \text { + granisetron } 1.5 \mathrm{mg} \text { iv }\end{array}$ & $\begin{array}{l}\text { All patients were covered } \\
\text { with drapes and a cotton } \\
\text { blanket. Fluids were } \\
\text { preheated to } 37^{\circ} \mathrm{C}\end{array}$ \\
\hline $\begin{array}{l}\text { Honarmand } \\
2008\end{array}$ & $\begin{array}{l}120 \text { patients } \\
18-60 \mathrm{yr}\end{array}$ & $\begin{array}{l}\text { orthopaedic } \\
\text { surgery }\end{array}$ & SA & $\begin{array}{l}\text { C(30) saline iv; } \\
\text { K(30) ketamine } 0.5 \\
\mathrm{mg} / \mathrm{kg} \mathrm{iv} \text {; }\end{array}$ & $\begin{array}{l}\text { M(30) midazolam } 75 \mu \mathrm{g} / \mathrm{kg} \text { iv; } \\
\mathrm{KM}(30) \mathrm{ketamine} 0.25 \mathrm{mg} / \mathrm{kg}+ \\
\text { midazolam } 37.5 \mu \mathrm{g} / \mathrm{kg} \text { iv }\end{array}$ & $\begin{array}{l}\text { Fluids were preheated } \\
\text { to } 37^{\circ} \mathrm{C}\end{array}$ \\
\hline Zahra 2008 & $\begin{array}{l}120 \text { patients } \\
5-12 \mathrm{yr}\end{array}$ & $\begin{array}{l}\text { tonsillectomy } \\
\text { surgery }\end{array}$ & GA & C(40):saline & $\begin{array}{l}\text { K(40):ketamine } 1 \mathrm{mg} / \mathrm{kg} ; \mathrm{P}(40) \text { :pethidine } \\
0.5 \mathrm{mg} / \mathrm{kg}\end{array}$ & None. \\
\hline Han 2010 & $\begin{array}{l}93 \text { patients } \\
51-78 \mathrm{yr}\end{array}$ & $\begin{array}{l}\text { transurethral } \\
\text { resection of } \\
\text { the prostate }\end{array}$ & SA & $\begin{array}{l}C(31) \text { : epidural } \\
0.75 \% \text { ropivacaine }\end{array}$ & $\begin{array}{l}\text { K1(32): epdural ketamine } 0.2 \mathrm{mg} / \mathrm{kg}+ \\
0.75 \% \text { ropivacaine; } \mathrm{K} 2(30) \text { : epidural } \\
\text { ketamine } 0.4 \mathrm{mg} / \mathrm{kg}+0.75 \% \text { ropivacaine }\end{array}$ & None \\
\hline Shakya 2010 & 120 patients & $\begin{array}{l}\text { Lower } \\
\text { abdominal } \\
\text { surgery }\end{array}$ & SA & C(40):saline iv & $\begin{array}{l}\mathrm{K}(40) \text { : ketamine } 0.25 \mathrm{mg} / \mathrm{kg} \mathrm{iv} ; \mathrm{O}(40) \text { : } \\
\text { ondansetron } 4 \mathrm{mg} \text { iv }\end{array}$ & $\begin{array}{l}\text { Patients were covered } \\
\text { with standard single } \\
\text { blanket }\end{array}$ \\
\hline $\begin{array}{l}\text { Ayatollahi } \\
2011\end{array}$ & $\begin{array}{l}120 \text { patients } \\
20-50 \mathrm{yr}\end{array}$ & $\begin{array}{l}\text { endoscopic } \\
\text { sinus surgery }\end{array}$ & GA & C(30): saline iv & $\begin{array}{l}\mathrm{K} 1(30): 0.3 \mathrm{mg} / \mathrm{kg} \text { iv; } \mathrm{K} 2(30): 0.5 \mathrm{mg} / \mathrm{kg} \\
\text { iv; } \mathrm{M}(30): \text { meperidine } 0.4 \mathrm{mg} / \mathrm{kg} \text { iv }\end{array}$ & $\begin{array}{l}\text { Patients were covered } \\
\text { with a cotton blanket }\end{array}$ \\
\hline $\begin{array}{l}\text { Norouzi } \\
2011\end{array}$ & $\begin{array}{l}120 \text { patients } \\
18-65 \mathrm{yr}\end{array}$ & $\begin{array}{l}\text { elective } \\
\text { orthopedic } \\
\text { surgery }\end{array}$ & GA & C(30):saline iv & $\begin{array}{l}\text { K1(30):ketamine } 0.125 \text { mg/kg iv;K2(30): } \\
\text { ketamine } 0.25 \mathrm{mg} / \mathrm{kg} \text { iv;K3(30):ketamine } \\
0.5 \mathrm{mg} / \mathrm{kg} \text { iv }\end{array}$ & None \\
\hline Wason 2012 & $\begin{array}{l}200 \text { patients } \\
18-65 \mathrm{yr}\end{array}$ & $\begin{array}{l}\text { ower abdominal } \\
\text { or lower limb } \\
\text { surgery }\end{array}$ & SA & C(50):saline iv & $\begin{array}{l}\mathrm{K}(50): \mathrm{ketamine} 0.5 \mathrm{mg} / \mathrm{kg} \text { iv; } \mathrm{C}(50) \text { :clonidine } \\
75 \mathrm{mcg} ; \mathrm{T}(50): \text { tramadol } 0.5 \mathrm{mg} / \mathrm{kg} \text { iv }\end{array}$ & $\begin{array}{l}\text { Fluids were preheated } \\
\text { to } 37^{\circ} \mathrm{C}\end{array}$ \\
\hline $\begin{array}{l}\text { Zavareh } \\
2012\end{array}$ & $\begin{array}{l}135 \text { patients } \\
18-70 \mathrm{yr}\end{array}$ & elective surgery & GA & $\begin{array}{l}\text { K(45):ketamine } 0.5 \\
\mathrm{mg} / \mathrm{kg} \text { iv; }\end{array}$ & $\begin{array}{l}\mathrm{P}(45) \text { :pethidine } 0.5 \mathrm{mg} / \mathrm{kg} ; \mathrm{D}(45) \text { : } \\
\text { dexamethasone, } 0.6 \mathrm{mg} / \mathrm{kg}\end{array}$ & None \\
\hline $\begin{array}{l}\text { Abdelhalim } \\
2014\end{array}$ & $\begin{array}{l}120 \text { patients } \\
18-45 \mathrm{yr}\end{array}$ & ENT surgery & GA & C(30): saline iv & $\begin{array}{l}\mathrm{O}(30) \text { : ondansetron } 8 \mathrm{mg} \text { iv; } \mathrm{K}(30) \text { : } \\
\text { ketamine } 0.5 \mathrm{mg} / \mathrm{kg} \text { iv; OK(30) } \\
\text { ondansetron } 8 \mathrm{mg}+\text { ketamine } \\
0.25 \mathrm{mg} / \mathrm{kg} \text { iv }\end{array}$ & None \\
\hline Petskul 2016 & $\begin{array}{l}183 \text { patients } \\
18-65 \mathrm{yr}\end{array}$ & $\begin{array}{l}\text { orthopedic } \\
\text { surgery }\end{array}$ & GA & C(92):saline iv & $\mathrm{K}(91)$ :ketamine $0.25 \mathrm{mg} / \mathrm{kg}$ iv & $\begin{array}{l}\text { All patients were warmed } \\
\text { by air force warmer }\end{array}$ \\
\hline $\begin{array}{l}\text { Mohtadi } \\
2016\end{array}$ & $\begin{array}{l}117 \text { patients } \\
18-40 \mathrm{yr}\end{array}$ & cesarean section & SA & C(39):saline iv & $\begin{array}{l}\mathrm{K}(39) \text { :ketamine } 0.25 \mathrm{mg} / \mathrm{kg}, \mathrm{iv} ; \mathrm{O}(39) \text { : } \\
\text { ondansetron } 4 \mathrm{mg} \text {,iv }\end{array}$ & None \\
\hline $\begin{array}{l}\text { Hasannasab } \\
2016\end{array}$ & $\begin{array}{l}120 \text { patients } \\
20-45 \mathrm{yr}\end{array}$ & $\begin{array}{l}\text { gynecologic } \\
\text { surgery }\end{array}$ & GA & $\begin{array}{l}\mathrm{K}(40) \text { : ketamine } \\
0.25 \mathrm{mg} / \mathrm{kg} \text { iv; }\end{array}$ & $\begin{array}{l}\mathrm{M}(40) \text { : meperidine } 20 \mathrm{mg} \text { iv; } \mathrm{D}(40) \text { : } \\
\text { doxapram } 0.25 \mathrm{mg} / \mathrm{kg} \text { iv }\end{array}$ & $\begin{array}{l}\text { Patients were covered } \\
\text { with a standard blanket }\end{array}$ \\
\hline Lakhe 2017 & $\begin{array}{l}120 \text { patients } \\
18-65 \text { years }\end{array}$ & $\begin{array}{l}\text { gynecological } \\
\text { and orthopedic } \\
\text { surgery }\end{array}$ & SA & C(30):saline,iv & $\begin{array}{l}\text { T(30):tramadol } 0.5 \mathrm{mg} / \mathrm{kg} \text { iv } \mathrm{O}(30) \text { : } \\
\text { ondansetron } 4 \mathrm{mg}, \mathrm{iv} ; \mathrm{K}(30): \mathrm{ketamine} \\
0.25 \mathrm{mg} / \mathrm{kg} \text { iv }\end{array}$ & $\begin{array}{l}\text { Patients were covered } \\
\text { with drapes }\end{array}$ \\
\hline Lema 2017 & $\begin{array}{l}123 \text { patients } \\
18-39 \mathrm{yr}\end{array}$ & cesarean section & SA & C(41):saline iv & $\begin{array}{l}\mathrm{K}(41): \mathrm{ketamine} 0.2 \mathrm{mg} / \mathrm{kg} \text { iv; } \mathrm{T}(41) \text { : } \\
\text { tramadol } 0.5 \mathrm{mg} / \mathrm{kg} \text { iv }\end{array}$ & $\begin{array}{l}\text { Patients were covered } \\
\text { with drapes }\end{array}$ \\
\hline
\end{tabular}

Abbreviations: $y r$ years; $G A$ general anesthesia; $S A$ spinal anesthesia; $C$ control; $O$ ondansetron; $T$ tramadol; $M$ meperidine; $D$ doxapram; $G$ granisetron; $C L$ clonidine; $P$ pethidine

reduced the incidence of postanesthetic shivering in general anesthesia (pooled OR $=0.13$; 95\% CI: 0.06 to 0.26 ) and in spinal anesthesia (pooled OR $=0.08$; $95 \%$ CI: 0.03 to 0.18 ). (Fig. 5) shows the subgroup analysis based on the dose of ketamine used in the included trials. Ketamine reduced the incidence of postanesthetic shivering at the dose of 0.25 $\mathrm{mg} / \mathrm{kg}$ (pooled OR $=0.12 ; 95 \%$ CI: 0.03 to 0.52 ) and at the dose of $0.5 \mathrm{mg} / \mathrm{kg}$ (pooled OR $=0.14 ; 95 \%$ CI: 0.07 to 0.28 ). We performed a subgroup analysis based on the type of surgery, as this may influence the incidence of postanesthetic shivering (Fig. 6). Ketamine significantly lowered the incidence of postanesthetic shivering in patients after orthopedic surgery (pooled $\mathrm{OR}=0.32 ; 95 \% \mathrm{CI}: 0.13$ to 0.77). Among patients undergoing abdominal, cesarean section, urological, ENT or endoscopic surgery, ketamine also reduced the incidence of postanesthetic shivering.

\section{Ketamine vs other pharmacological interventions}

A total of four studies [12, 13, 23, 24] investigated the effect of ketamine on the prevention of shivering compared with pethidine. The pooled analysis showed a definite difference in favor of pethidine (pooled $\mathrm{OR}=4.38$; $95 \%$ CI: 1.76 to 10.92$)$. No significant difference in postanesthetic shivering was found between ketamine and other pharmacological interventions (Fig. 7). 

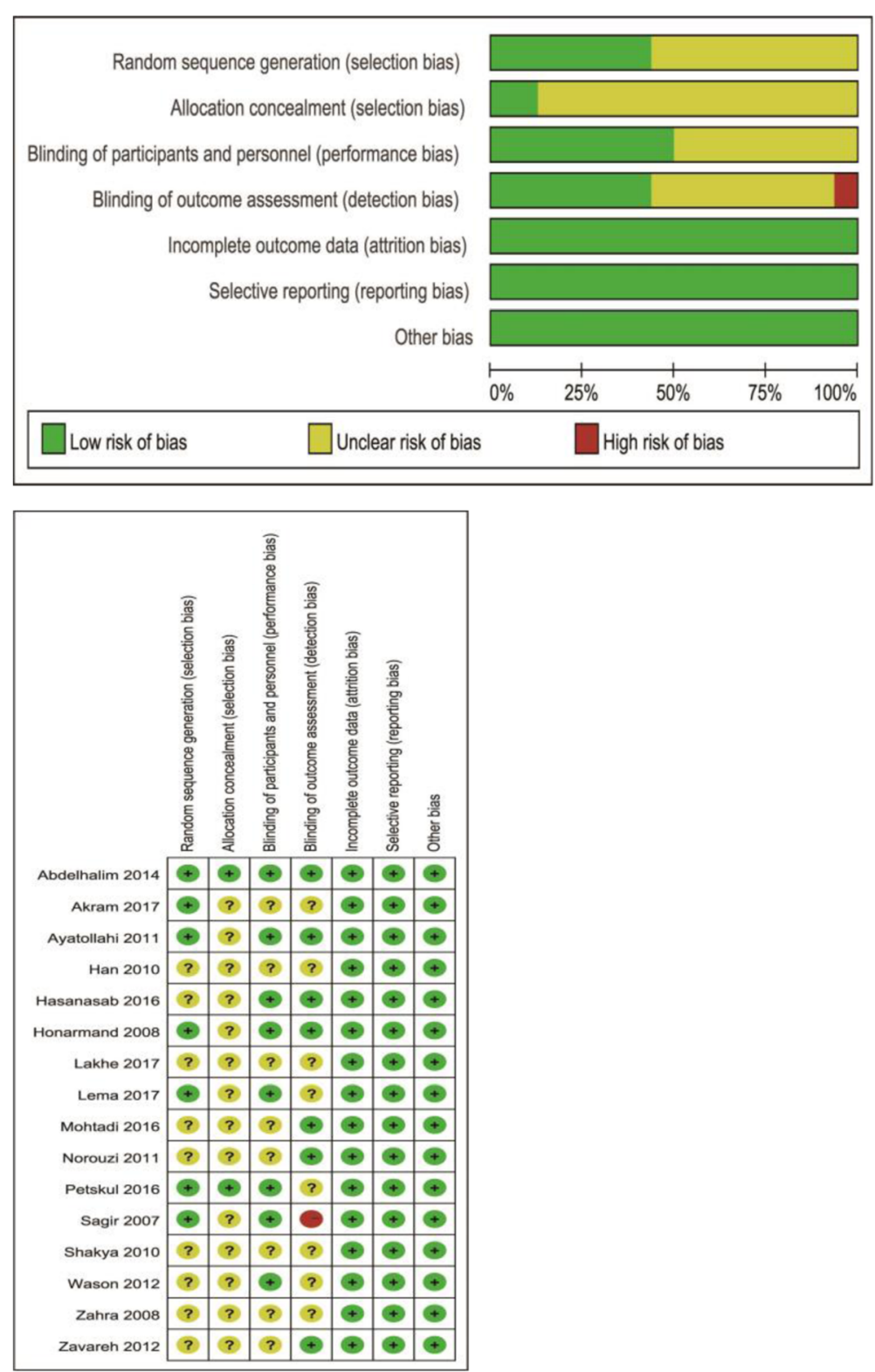

Fig. 2 Risk of bias graph and summary

\section{Secondary outcomes}

\section{Ketamine vs placebo}

Except for the other side effects (hypotension, bradycardia, hallucination), there was no significant difference in the incidence of postoperative nausea and vomiting (PONV) between ketamine and the placebo (pooled $\mathrm{RR}=0.72$; 95\% CI: 0.48 to 1.08 ) (Table 2). Ketamine reduced the incidence of hypotension and bradycardia compared with the placebo (pooled $\mathrm{RR}=0.28 ; 95 \% \mathrm{CI}$ : 0.17 to 0.47 ; pooled $\mathrm{RR}=0.18$; $95 \% \mathrm{CI}: 0.05$ to 0.65 ). The incidence of hallucination was more significant and prevalent in the patients who received $0.5 \mathrm{mg} / \mathrm{kg}$ ketamine (Table 3); there was only one episode of hallucination in patients receiving $0.25 \mathrm{mg} / \mathrm{kg}$. A pooled analysis was not performed because of the lack of uniform sedation score scales in the trials. All of these studies showed that the patients in the ketamine group were more sedated compared to the placebo group. Five trials $[14,16,17,19,23]$ reported a significant decrease in core temperature in both the ketamine and placebo groups compared to the baseline temperature of participants. However, it was not significant between groups, at any time point. Three trials [20-22] reported a significant difference in core temperature between ketamine and the placebo; a greater decrease in temperature was found in the placebo group. 


\begin{tabular}{|c|c|c|c|c|c|c|c|c|c|c|}
\hline Studv or Subgroup & \multicolumn{2}{|c|}{ ketamine } & \multicolumn{2}{|c|}{ piacebo } & \multicolumn{2}{|c|}{ Odds Ratio } & \multicolumn{4}{|c|}{$\begin{array}{c}\text { Odds Ratio } \\
\text { M-H. Random. } 95 \% \mathrm{Cl}\end{array}$} \\
\hline Sagir 2007 & 0 & 40 & 22 & 40 & $4.0 \%$ & $0.01[0.00,0.18]$ & 2007 & $\leftarrow$ & & \\
\hline Zabra 2008 & 1 & 40 & 17 & 40 & $5.7 \%$ & $0.03[0.00,0.28]$ & 2008 & $\longleftarrow$ & & \\
\hline Honarmand 2008 & 7 & 30 & 15 & 30 & $8.9 \%$ & $0.30[0.10,0.92]$ & 2008 & & & \\
\hline Shakya 2010 & 1 & 40 & 17 & 40 & $5.7 \%$ & $0.03[0.00,0.28]$ & 2010 & & & \\
\hline Han 2010 & 1 & 62 & 12 & 31 & $5.7 \%$ & $0.03[0.00,0.21]$ & 2010 & $\longleftrightarrow$ & & \\
\hline Norouzi 2011 & 41 & 90 & 22 & 30 & $9.6 \%$ & $0.30[0.12,0.76]$ & 2011 & & & \\
\hline Ayatollahi 2011 & 4 & 60 & 9 & 30 & $8.3 \%$ & $0.17[0.05,0.60]$ & 2011 & & & \\
\hline Wason 2012 & 9 & 50 & 36 & 50 & $9.5 \%$ & $0.09[0.03,0.22]$ & 2012 & & & \\
\hline Abdelhalim 2014 & 3 & 30 & 12 & 30 & $7.9 \%$ & $0.17[0.04,0.67]$ & 2014 & & & \\
\hline Petskul 2016 & 13 & 91 & 15 & 92 & $9.9 \%$ & $0.86[0.38,1.92]$ & 2016 & & & \\
\hline Mohtadi 2016 & 2 & 39 & 28 & 39 & $7.2 \%$ & $0.02[0.00,0.10]$ & 2016 & $\longleftarrow$ & & \\
\hline Lakhe 2017 & 3 & 30 & 17 & 30 & $7.9 \%$ & $0.08[0.02,0.34]$ & 2017 & & & \\
\hline Lema 2017 & 17 & 41 & 23 & 41 & $9.7 \%$ & $0.55[0.23,1.33]$ & 2017 & & + & \\
\hline Total $(95 \% \mathrm{Cl})$ & & 643 & & 523 & $100.0 \%$ & $0.13[0.06,0.26]$ & & & & \\
\hline Total events & 102 & & 245 & & & & & & & \\
\hline Heterogeneity: Tauz & 1.13; $\mathrm{Chi}^{2}$ & $=46.0$ & $1, d f=12$ & $2(P<0$ & $0.00001) ;$ & $I^{2}=74 \%$ & & 0.01 & 10 & 100 \\
\hline Test for overall effect & $Z=5.74$ & $P<0.0$ & 0001) & & & & & Favours [experimental] & Favours [control] & \\
\hline
\end{tabular}

Ketamine vs other pharmacological interventions

No significant difference was found in the incidence of PONV between ketamine and pethidine (pooled OR = 0.88; $95 \%$ CI: 0.38 to 2.07 ). Compared to tramadol, the difference in the incidence of PONV and hypotension is not significant $(\mathrm{OR}=0.57 ; 95 \% \mathrm{CI}: 0.18$ to 178 ; $\mathrm{OR}=$ 0.90; $95 \%$ CI: 0.36 to 2.24). The incidence of PONV was higher in the ketamine group than the ondansetron group $(\mathrm{OR}=4.49$; $95 \% \mathrm{CI}$ : 1.24 to 16.21$)$. However, ketamine showed a lower incidence of hypotension compared to ondansetron $(\mathrm{OR}=0.09 ; 95 \% \mathrm{CI}$ : 0.00 to 3.23$)$. Core temperature changes were reported graphically; there was no significant difference between ketamine and other pharmacological interventions.

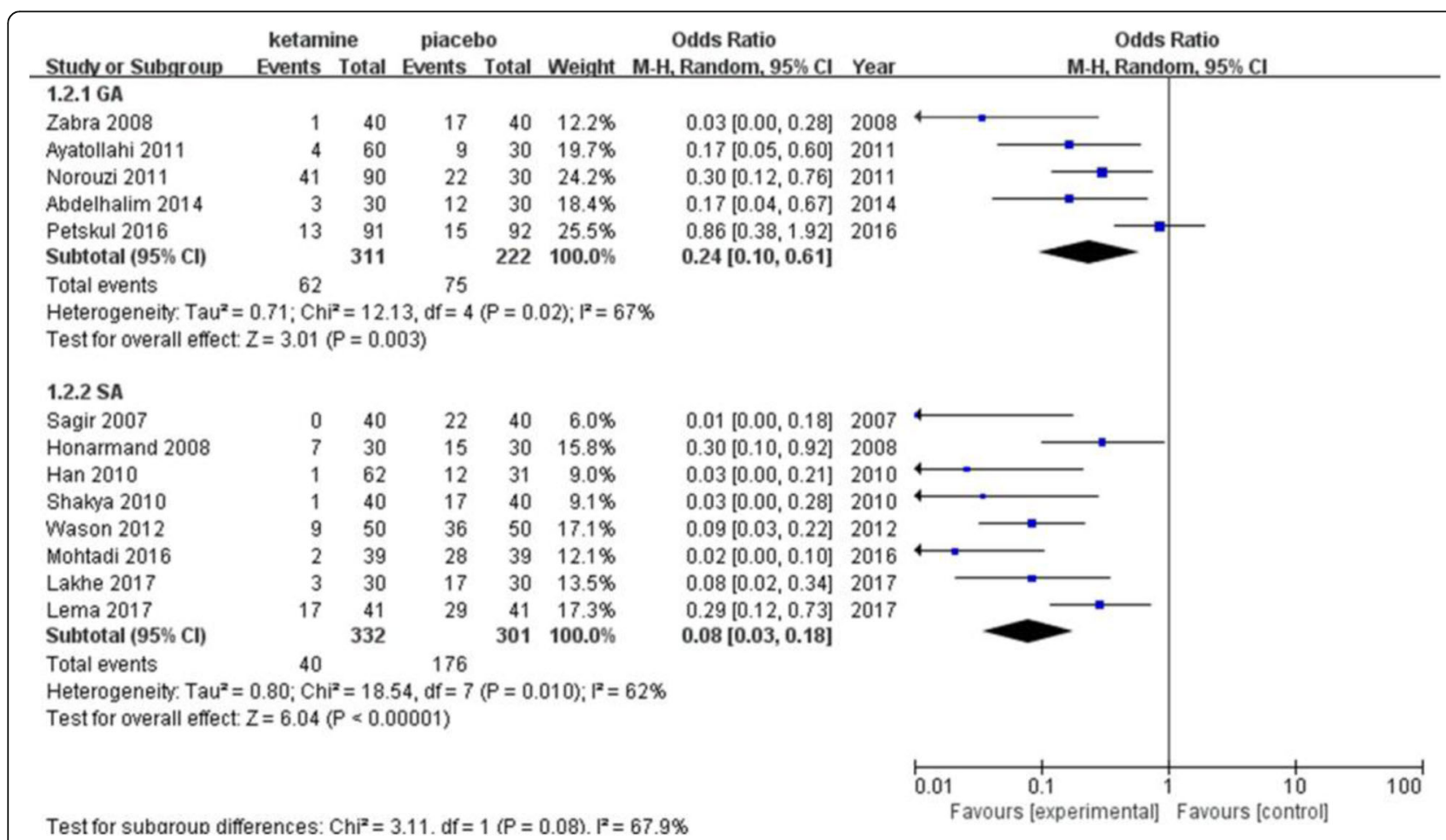

Fig. 4 Result of subgruop analysis according to different anesthetic methods. Cl, confidence interval; GA, genaral anesthesia; SA, spinal anesthesia 


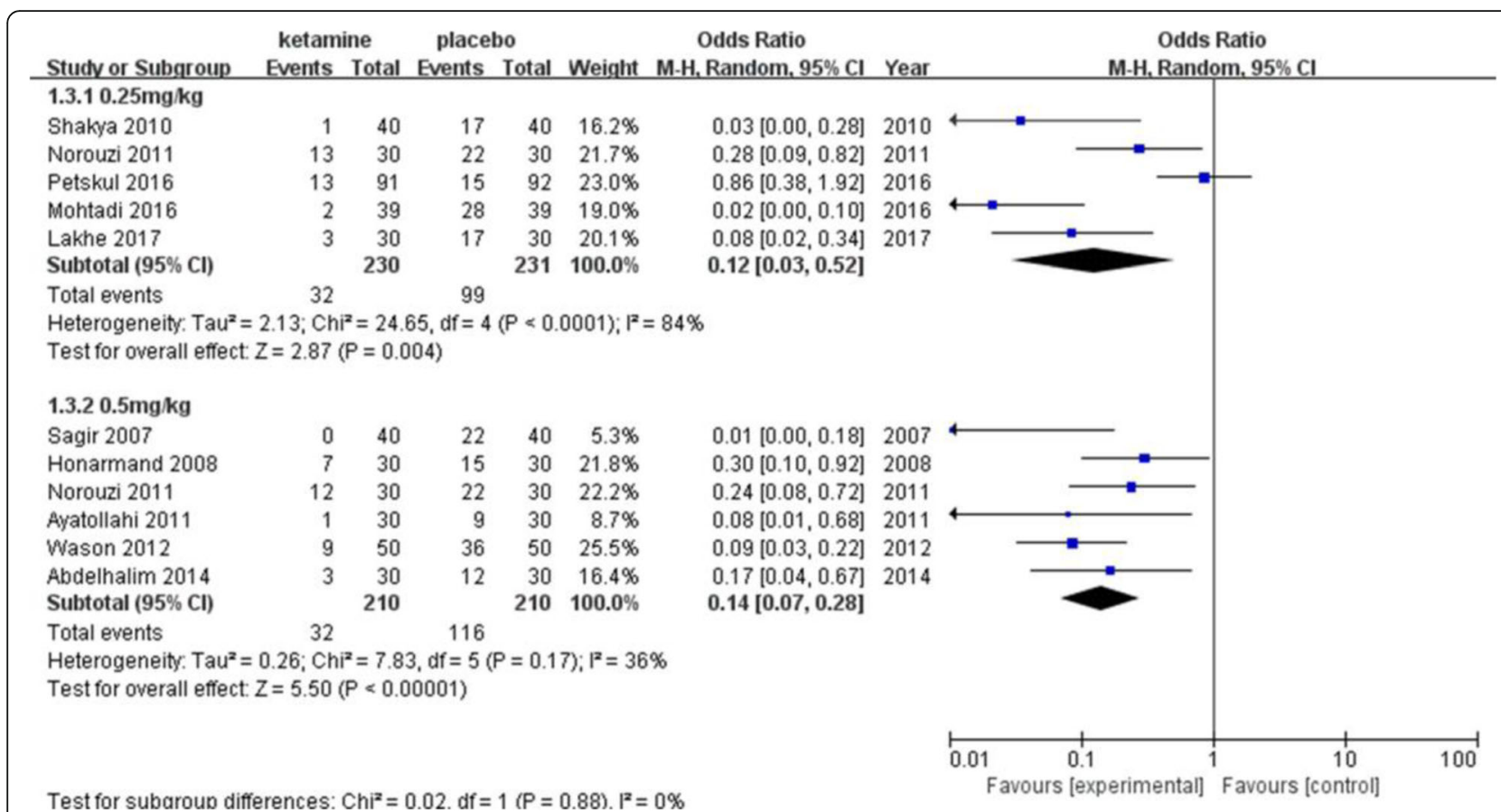

Fig. 5 Result of subgruop analysis according to different doses of ketamine administrated. Cl indicates confidence interval

\section{Summary of findings and quality of evidence}

The Summary of findings with GRADE recommendations are shown in Table 4.

\section{Discussion}

In the present study, we compared different randomized controlled trials to identify the beneficial aspects of ketamine. We compared the usage of ketamine and its relevance in anaesthetic shivering. In total, 16 studies including 1485 patients were analysed.

Ketamine was first synthesized in the early 1960s as a safe alternative to phencyclidine [26]. It is a noncompetitive -NMDA receptor antagonist with an effect of thermoregulation. Other than being a competitive NMDA receptor antagonist, ketamine also acts as an opioid agonist [27]. Further, it can cause blockage of amine uptake in the descending inhibitory monoaminergic pain pathways, having a local anaesthetic action and interacting with the muscarinic receptors [28]. In contrast, even at sub-anaesthetic doses, ketamine might cause a dissociative state, characterised by a sense of detachment from one's physical body and the external world (depersonalization and derealization). Ketamine probably controls shivering by acting on non-shivering thermogenesis [29]. Ketamine is predominantly utilized as an anaesthetic agent that induces analgesia but for a long time it has been criticized for some of its side effects which include the induction of a psychedelic state causing agitation and hallucinations [30].
The key findings of our analysis are as follows. Ketamine exposure was relatively better in reducing the occurrence of postanaesthetic shivering compared to placebo. Compared with tramadol and ondansetron, ketamine slightly lowered the incidence of postanaesthetic shivering although not significantly. The effect of ketamine on postanaesthetic shivering remained equally beneficial for both spinal and general types of anaesthesia. A dose of $0.5 \mathrm{mg} / \mathrm{kg}$ had an advance effect compared to $0.25 \mathrm{mg} / \mathrm{kg}$ on the postanaesthetic shivering rate. The effect remained constant for all types of surgical procedures including orthopaedic surgery, laparotomy, caesarean section, urological, ENT, and endoscopic surgeries. Compared to ketamine, pethidine showed a quicker responsive rate. However, sufficient data was not available in other studies to show any advantage of other pharmacological interventions.

Furthermore, we evaluated the side effects of the anaesthetic drugs and the role of ketamine in preventing or overcoming the effects. Moreover, the efficacy of ketamine was compared with a placebo. The side effects observed in the trials were nausea, vomiting, hypotension, bradycardia, and hallucinations. Ketamine showed a favourable outcome in reducing the incidence rate of hypotension and bradycardia as ketamine causes dose dependent direct stimulation of the CNS which leads to increased sympathetic nervous system stimulation followed by increased systemic blood pressure and heart rate.

However, there was no effect of ketamine in decreasing the incidence rate of nausea and vomiting as 


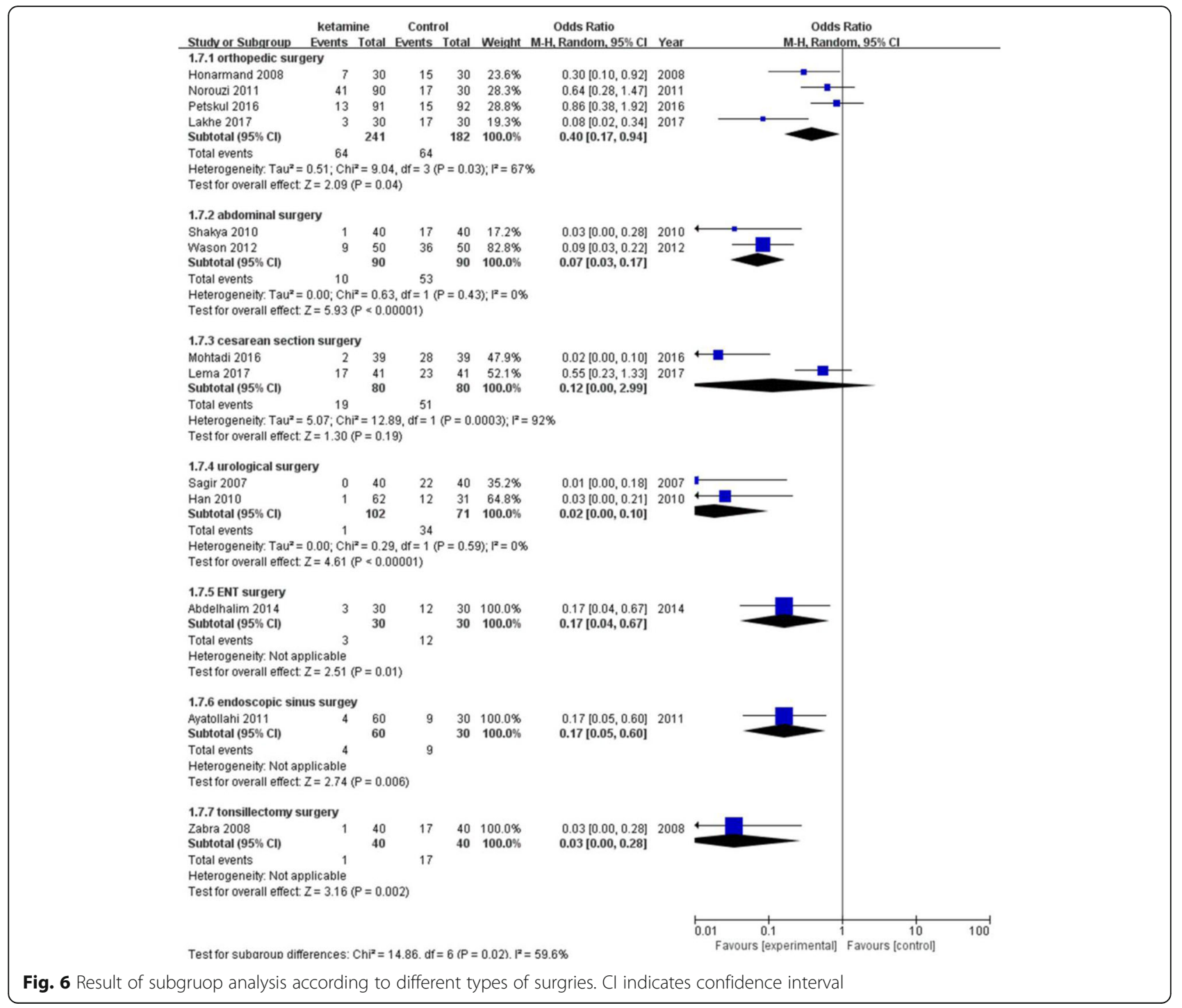

compared to placebo. As ketamine is known to have a hallucinogenic effect, it is considered to have a potential role in glutamatergic signalling in psychosis; therefore, the usage of ketamine is suggested to be associated with auditory and verbal hallucinations. In our comparative study, we also found that the rate of occurrence of hallucination episodes was much higher in patients receiving a ketamine dose of $0.5 \mathrm{mg} / \mathrm{kg}$ compared to a lower dose of $0.25 \mathrm{mg} / \mathrm{kg}$. The hallucinogenic effect of ketamine was evident when compared with the placebo drugs, for which there was no incidence of hallucinations reported in any of the trials. Ketamine can cause sedation in postoperative patients and deep sedation is considered to be a severe adverse event. However, for those experiencing shivering, mild sedation may prevent them from hurting themselves. In our study, we paid special attention to the sedation score of patients, although pooled analysis was not conducted because of various sedation scales. We found that mild to moderate sedation was more commonly seen in patients receiving different doses of ketamine.

Besides various pharmacological interventions above, we noticed that active warming for elective caesarean delivery reduced the incidence of postoperative shivering and provided more stable perioperative temperature change ${ }^{[31]}$. Accumulating evidence has shown that the active warming method including electric heating, water-circulating garments, forced-air, and radiant heating is effective in preventing post-anaesthetic shivering. The current American Society of Anesthesiologists Task Force on Postanesthetic Care guidelines recommend forced-air warming as a common method to reduce shivering in the perioperative setting ${ }^{[32]}$. Future research should focus on combinations of pharmacological interventions with non-pharmacological methods to better solve this problem. 


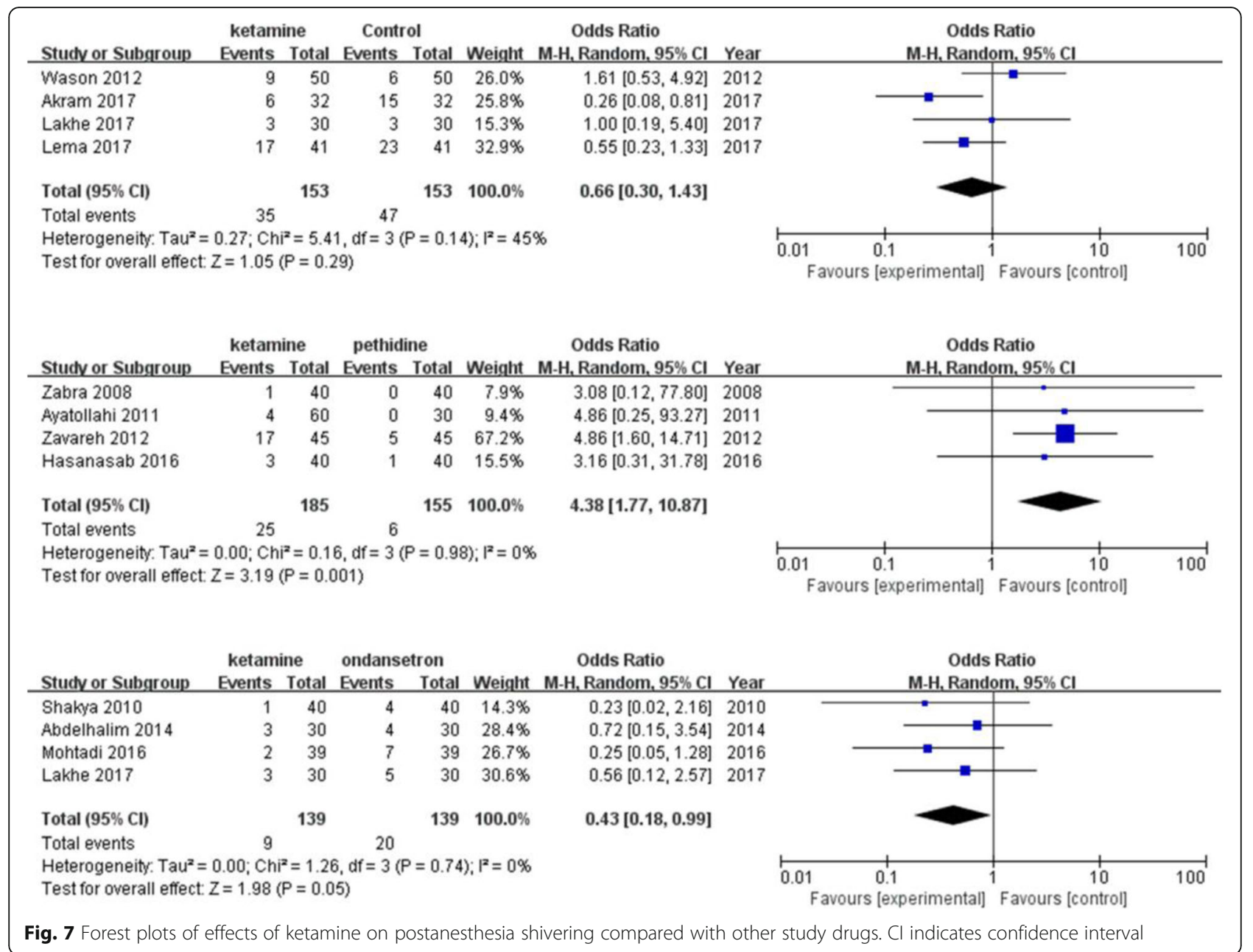

The major limitation of our study is that we could not study the hemodynamical changes related to ketamine usage as there were no standard criteria being followed by the trials causing irrelevancy and uneven data for comparing and evaluating precise outcomes in this regard. Second, the sample size of included trials was relatively small which may decrease generalisability of our conclusions. Third, the evidence level for our outcomes was low or very low. However, we believe that our study is of value because it provided clear evidence of the benefit of prophylactic ketamine intervention for preventing post-anaesthetic shivering which may be helpful in clinical practice.

\section{Conclusion}

In this meta-analysis, we assessed various aspects of ketamine usage in controlling post-anaesthetic shivering. We found that ketamine reduced the incidence rate of shivering compared to the placebo. Although it is beneficial, it did not show any superiority over other pharmacological interventions. Ketamine is of clinical value, but further studies should be performed on a wider scale to determine more emphasized results. Furthermore, larger clinical trials investigating the combination of different anti-shivering regimens are warranted.

Table 2 Comparisons of incidence of other side effects

\begin{tabular}{lllll}
\hline Side effccts & Number of studies & Ketamine & Placebo & \\
\hline Nausea and vomitting & & Events/Total & Events/Total & Odds Ratio (95\% Cl) \\
Hypotension & 11 & $48 / 523$ & $57 / 463$ & $0.70[0.44,1.12]$ \\
Bradycardia & 6 & $23 / 302$ & $61 / 271$ & $0.30[0.18,0.49]$ \\
Hallucination & 2 & $3 / 112$ & $11 / 81$ & $0.14[0.04,0.52]$ \\
\hline
\end{tabular}


Table 3 Episodes of hallucination based on the dose of ketamine

\begin{tabular}{llll}
\hline Study ID & $\begin{array}{l}\text { Dose of } \\
\text { ketamine }\end{array}$ & $\begin{array}{l}\text { Ketamine } \\
\text { Events/Total }\end{array}$ & $\begin{array}{c}\text { Placebo } \\
\text { Events/Total }\end{array}$ \\
\hline Honarmand 2008 & $0.5 \mathrm{mg} / \mathrm{kg}$ & $3 / 30$ & $0 / 30$ \\
Han 2010 & $0.4 \mathrm{mg} / \mathrm{kg}$ & $2 / 30$ & $0 / 31$ \\
Norouzi 2011 & $0.25 \mathrm{mg} / \mathrm{kg}$ & $1 / 30$ & $0 / 30$ \\
Norouzi 2011 & $0.5 \mathrm{mg} / \mathrm{kg}$ & $4 / 30$ & $0 / 30$ \\
Ayatollahi 2011 & $0.5 \mathrm{mg} / \mathrm{kg}$ & $3 / 30$ & $0 / 30$ \\
Abdelhalim 2014 & $0.5 \mathrm{mg} / \mathrm{kg}$ & $1 / 30$ & $0 / 30$ \\
\hline
\end{tabular}

Table 4 Summary of findings with GRADE recommendations

\begin{tabular}{|c|c|c|c|c|c|}
\hline \multicolumn{6}{|c|}{ ketamine for postoperative shivering } \\
\hline \multicolumn{6}{|c|}{ Patient or population: patients with postoperative shivering } \\
\hline \multicolumn{6}{|l|}{ Settings: hospitals } \\
\hline \multicolumn{6}{|l|}{ Intervention: ketamine } \\
\hline \multirow[t]{3}{*}{ Outcomes } & \multicolumn{2}{|c|}{ Illustrative comparative risks ${ }^{\mathrm{a}}(95 \% \mathrm{Cl})$} & \multirow{3}{*}{$\begin{array}{l}\text { Relative effect } \\
(95 \% \mathrm{Cl})\end{array}$} & \multirow{3}{*}{$\begin{array}{l}\text { No of Participants } \\
\text { (studies) }\end{array}$} & \multirow{3}{*}{$\begin{array}{l}\text { Quality of the } \\
\text { evidence (GRADE) }\end{array}$} \\
\hline & Assumed risk & Corresponding risk & & & \\
\hline & Control & Ketamine & & & \\
\hline \multirow[t]{4}{*}{ Incidence of shivering } & \multicolumn{2}{|c|}{ Study population } & \multirow[t]{4}{*}{ OR 0.13 (0.06 to 0.26 ) } & \multirow[t]{4}{*}{1166 (13 studies) } & \multirow[t]{4}{*}{$\oplus \oplus \ominus \ominus$ low $^{1}$} \\
\hline & 468 per 1000 & 103 per 1000 (50 to 186$)$ & & & \\
\hline & Moderate & & & & \\
\hline & 500 per 1000 & 115 per 1000 (57 to 206$)$ & & & \\
\hline \multirow[t]{4}{*}{ Nausea and vomitting } & \multicolumn{2}{|c|}{ Study population } & \multirow[t]{4}{*}{ OR 0.7 (0.44 to 1.12$)$} & \multirow[t]{4}{*}{986 (11 studies) } & \multirow[t]{4}{*}{$\oplus \oplus \ominus \ominus \mathrm{low}^{1}$} \\
\hline & 123 per 1000 & 89 per 1000 (58 to 136$)$ & & & \\
\hline & Moderate & & & & \\
\hline & 125 per 1000 & 91 per 1000 (59 to 138) & & & \\
\hline \multirow[t]{4}{*}{ Hypotension } & \multicolumn{2}{|c|}{ Study population } & \multirow[t]{4}{*}{ OR 0.3 (0.18 to 0.49 ) } & \multirow[t]{4}{*}{573 (7 studies) } & \multirow[t]{4}{*}{$\oplus \Theta \Theta \Theta$ very low ${ }^{1}$} \\
\hline & 225 per 1000 & 80 per 1000 (50 to 125 ) & & & \\
\hline & Moderate & & & & \\
\hline & 200 per 1000 & 70 per 1000 (43 to 109) & & & \\
\hline \multirow[t]{4}{*}{ Bradycardia } & \multicolumn{2}{|c|}{ Study population } & \multirow[t]{4}{*}{ OR 0.14 (0.04 to 0.52 ) } & \multirow[t]{4}{*}{193 (2 studies) } & \multirow[t]{4}{*}{$\oplus \ominus \ominus \ominus$ very low ${ }^{1}$} \\
\hline & 136 per 1000 & 22 per 1000 (6 to 76$)$ & & & \\
\hline & Moderate & & & & \\
\hline & 165 per 1000 & 27 per 1000 (8 to 93) & & & \\
\hline \multirow[t]{4}{*}{ Hallucination } & \multicolumn{2}{|c|}{ Study population } & \multirow[t]{4}{*}{ OR 4.41 (1.14 to 17.07 ) } & \multirow[t]{4}{*}{423 (5 studies) } & $\oplus \ominus \ominus \ominus$ very low ${ }^{1}$ \\
\hline & 0 per 1000 & 0 per 1000 (0 to 0 ) & & & \\
\hline & Moderate & & & & \\
\hline & 0 per 1000 & 0 per 1000 (0 to 0$)$ & & & \\
\hline
\end{tabular}

${ }^{a}$ The basis for the assumed risk (e.g. the median control group risk across studies) is provided in footnotes. The corresponding risk (and its $95 \%$ confidence interval) is based on the assumed risk in the comparison group and the relative effect of the intervention (and its $95 \% \mathrm{Cl}$ )

Cl Confidence interval; OR Odds ratio;

GRADE Working Group grades of evidence

High quality: Further research is very unlikely to change our confidence in the estimate of effect

Moderate quality: Further research is likely to have an important impact on our confidence in the estimate of effect and may change the estimate

Low quality: Further research is very likely to have an important impact on our confidence in the estimate of effect and is likely to change the estimate

Very low quality: We are very uncertain about the estimate 


\section{Abbreviations}

CNS: Central nervous system; ECG: Electrocardiography; ENT: Ear-nose-throat; NMDA: N-methy-D-aspartate; PONV: Postoperative nausea and vomiting; PRISMA: Reporting Items for Systematic Reviews and Meta-Analysis; SpO2: Oxygen saturation

\section{Acknowledgements}

Not applicable.

\section{Authors' contributions}

YZ was involved in the study design, participated in drafting the manuscript and also helped to analyse the study data. AM was involved in drafting the manuscript and performed the data analysis. YH, HL, HLG, XG, MSD were participated in study design and drafting the manuscript. J.L.C conceived of the study and helped to revise the manuscript. All authors have read and approved the manuscript.

\section{Funding}

This study was support by the National Natural Science Foundation of China Grant Nos. 81070888 and 81230025 (to J-LC). The funding agents play no role in the design of the study and collection, analysis, and interpretation of data and in writing the manuscript.

\section{Availability of data and materials}

The datasets used in the analysis was collected by online search, and the datasets analyzed in the current study are available from the corresponding author on reasonable request.

\section{Ethics approval and consent to participate}

Not applicable.

\section{Consent for publication}

Not applicable.

\section{Competing interests}

The authors declare that they have no competing interests.

Received: 3 June 2019 Accepted: 9 December 2019

Published online: 30 December 2019

\section{References}

1. Insler SR, Sessler DI. Perioperative thermoregulation and temperature monitoring. Anesthesiol Clin. 2006;24:823-37.

2. Alfonsi P. Postanaesthetic Shivering. Drugs. 2001;61:2193-205.

3. Horn EP, Schroeder F, Wilhelm S, et al. Postoperative pain facilitates nonthermoregulatory tremor. Anesthesiol. 1999;91:979-84.

4. Lenhardt R. The effect of anesthesia on body temperature control [J]. Front Biosci. 2010:2:1145-54.

5. Moeen SM, Moeen AM. Intrathecal dexamethasone vs meperidine for prevention of shivering during transurethral prostatectomy: a randomized controlled trial. Acta Anaesthesiol Scand. 2017;61:749-57.

6. Lyons B, Carroll M, McDonald NJ. The treatment of postanaesthetic shivering: a double blind comparison between alfentanil and pethidine. Acta Anaesthesiol Scand. 1995;39:979-82.

7. Sachidananda R, Basavaraj K, Shaikh SI, Umesh G, Bhat T, Arpitha B. Comparison of prophylactic intravenous magnesium sulfate with tramadol for Postspinal shivering in elective cesarean section: a placebo controlled randomized double-blind pilot study. Anesth Essays Res. 2018;12:130-4.

8. Nallam SR, Cherukuru K, Sateesh G. Efficacy of intravenous Ondansetron for prevention of Postspinal shivering during lower segment cesarean section: a double-blinded randomized trial. Anesth Essays Res. 2017;11:508-13.

9. Bock M, Bauer M, Rosler L, Sinner B, Motsch J. Dolasetron and shivering. A prospective randomized placebo-controlled pharmaco-economic evaluation. Anaesthesist. 2007;56:63-6 8-70.

10. Abdelhalim AA, Harethy SA, Alarfaj AM. Use of Ondansetron, ketamine or their combination for prevention of post-anesthetic shivering. J Alex Soc Anesth Intensive. 2014;12:121-70.

11. Akram M, Raza H, Imam SM, Akram M, Raza H, Imam SM. Efficacy of prophylactic low dose ketamine and tramadol for prevention of shivering during spinal anaesthesia in patients undergoing lower abdominal surgeries. Pak J Med Health Sci. 2017;11:378-80.
12. Ayatollahi V, Hajiesmaeili MR, Behdad S, Gholipur M, Abbasi HR. Comparison of prophylactic use of meperidine and two low doses of ketamine for prevention of post-anesthetic shivering: a randomized double-blind placebo controlled trial. J Res Med Sci. 2011;16:1340-6.

13. Hasannasab B, Banihashem N, Khoshbakht A. Prophylactic effects of Doxapram, Ketamine and Meperidine in Postoperative Shivering. Anesth Pain Med. 2016;6:e27515.

14. Honarmand A, Safavi MR. Comparison of prophylactic use of midazolam, ketamine, and ketamine plus midazolam for prevention of shivering during regional anaesthesia:a randomized double-blind placebo controlled trial. $\mathrm{Br}$ J Anaesth. 2008;101:557-62.

15. Lakhe G, Adhikari KM, Khatri K, Maharjan A, Bajracharya A, Khanal H. Prevention of shivering during spinal anesthesia: comparison between tramadol, ketamine and Ondansetron. JNMA J Nepal Med Assoc. 2017;56: 395-400.

16. Lema GF, Gebremedhn EG, Gebregzi AH, Desta YT, Kassa AA. Efficacy of intravenous tramadol and low-dose ketamine in the prevention of postspinal anesthesia shivering following cesarean section: a double-blinded, randomized control trial. Int J Women's Health. 2017;9:681-8.

17. Mohtadi AR, Goushe SMR, Ghomeishi A, Arbabi N. Comparison of preventive effect of low dose ketamine and ONDANSETRON in the prevention of shivering after spinal anesthesia in patients undergoing elective cesarean section. World J Pharm Pharm Sci. 2016;5:173-84.

18. Norouzi M, Doroodian MR, Salajegheh S. Optimum dose of ketamine for prevention of postanesthetic shivering; a randomized double-blind placebocontrolled clinical trial. Acta Anaesthesiol Belg. 2011;62:33-6.

19. Petskul S, Kitsiripant C, Rujirojindakul P, Chantarokorn A, Jullabunyasit A, Thinchana S. Prophylactic Low-Dose Ketamine to Prevent Post Anesthetic Shivering in Orthopedic Surgery: A Randomized-Controlled Study. J Med Assoc Thai = Chotmaihet thangphaet 2016; 99: 400-405.

20. Sagir O, Gulhas N, Toprak H, Yucel A, Begec Z, Ersoy O. Control of shivering during regional anaesthesia: prophylactic ketamine and granisetron. Acta Anaesthesiol Scand. 2007;51:44-9.

21. Shakya S, Chaturvedi A, Sah BP. Prophylactic low dose ketamine and ondansetron for prevention of shivering during spinal anaesthesia. J Anaesthesiol Clin Pharmacol. 2010;26:465-9.

22. Wason R, Jain N, Gupta P, Gogia AR. Randomized double-blind comparison of prophylactic ketamine, clonidine and tramadol for the control of shivering under neuraxial anaesthesia. Indian J Anaesth. 2012;56:370-5.

23. Zahra FA, Abudallah HM, Shabana Rl, Abdulmageed WM, Abdulrazik SI, Nassar AM. Intramuscular ketamine for prevention of postanesthesia shivering in children. Saudi Med J. 2008;29:1255-9.

24. Zavareh SMHT, Morovati L, Koushki AM. A comparative study on the prophylactic effects of ketamine, dexamethasone, and pethidine in preventing postoperative shivering. J Res Med Sci. 2012;17:S175-S81.

25. Han DY, Jeong HJ, Lee C, Choi DH. The efficacy of epidural ketamine on shivering during transurethral resection of the prostate under epidural anesthesia. Int Neurourol J. 2010;14:105-11.

26. Niesters M, Martini C, Dahan A. Ketamine for chronic pain: risks and benefits. Br J Clin Pharmacol. 2014;77(2):357-67.

27. Dar AM, Qazi SM, Sidiq S. A placebo-controlled comparison of ketamine with pethidine for the prevention of postoperative shivering. South Afr J Anaesth Analg. 2013;18:340-3.

28. Aroni F, lacovidou N, Dontas I, et al. Pharmacological aspects and potential new clinical applications of ketamine: reevaluation of an old drug [J]. J Clin Pharmacol. 2013;49(8):957-64.

29. Sharma DR, Thakur JR. Ketamine and shivering. Anaesth. 2010;45:252-3.

30. De Witte J, Sessler DI. Perioperative shivering: physiology and pharmacology. Anesthesiol. 2002;96:467-84.

\section{Publisher's Note}

Springer Nature remains neutral with regard to jurisdictional claims in published maps and institutional affiliations. 